\title{
TSC2 Gene Rearrangement
}

National Cancer Institute

\section{Source}

National Cancer Institute. TSC2 Gene Rearrangement. NCI Thesaurus. Code C153526.

A molecular abnormality indicating rearrangement of the TSC2 gene. 